\title{
PEMBINAAN PERILAKU KEBERAGAMAAN REMAJA BERBASIS IPTEKS
}

\author{
Muhibbin Syah,Bambang ${ }^{1}$, Nurul Fadhilah ${ }^{2}$ dan Syamsul Arifin ${ }^{3}$ \\ Program Pascasarjana UIN Sunang Gunung Djati , Jl. A.H. Nasution. No. I05. \\ Bandung \\ nfadhilah1@gmail.com
}

\begin{abstract}
This study aims to identify the effectiveness of IPTEKs (Science, Technology and Art) based behavior guidance for teenagers. Teenagers' religious awareness, specially at the early teen age around 13-17 years old, usually starts to have some turbulences. It can be seen when the teenagers tend to not continue studying in madrasah (Quran school) after they enter the Junior High School. Therefore, many teenagers easily access porn videos as a result of their gadget's misuse. From that phenomenon, an interesting and up-to-date religious behavior guidance is needed to attract the teenagers to follow. An education institution Salman ITB's Islamic Teenagers' Family (Karisma ITB) has invented an IPTEKs based media to guide the religious behavior of the teenagers. Our study in that institution proves that IPTEKs based religious behavior guidance is effective to guide the teenagers' behavior because it has fulfilled the teenagers' expectation and successfully change the teenagers' behavior to be better measured from the five dimensions of religiosity; faith dimension, worship dimension, comprehension dimension, experience dimension, and knowledge of religion. Teenagers' guidance in education institution of Karisma ITB is also in line with the Islamic education because it consists of the Islamic education's objective; spiritual education, physical education, and social education.
\end{abstract}

Keywords: Guidance, Teenagers' behavior, Science, Technology, Arts

\begin{abstract}
Abstrak : Penelitian ini bertujuan untuk mengetahui keefektifan pembinaan perilaku remaja berbasis IPTEKs ( Ilmu pengetahuan, teknologi dan seni). Kondisi kesadaran beragama remaja, khususnya usia remaja awal sekitar 13-17 tahun mulai mengalami kegoncangan. Bisa dilihat dari remaja tidak melanjutkan lagi mengaji di madrasah ketika mereka mulai memasuki SMP, hingga banyak remaja yang mudah mengakses video porno akibat menyalah gunakan gawainya. Dari fenomena tersebut dibutuhkan model pembinaan perilaku keberagamaan yang dapat menarik minat remaja untuk mengikutinya dan sesuai dengan perkembangan zaman. Lembaga pendidikan keluarga remaja masjid salman ITB telah berinovasi dalam membina perilaku keberagamaan remaja dengan media IPTEKs. Pada penelitian di lembaga tersebut dihasilkan simpulan bahwa pembinaan perilaku keberagamaan remaja berbasis IPTEKs efektif dalam membina perilaku remaja karena telah memenuhi harapan-harapan remaja dan merubah perilaku remaja menjadi lebih baik diukur dari peningkatan lima aspek keberagamaan yaitu aspek keyakinan, aspek peribadatan, aspek penghayatan, aspek pengalaman dan pengetahuan agama. Pembinaan remaja di lembaga pendidikan keluarga remaja masjid salman ITB juga telah sesuai dengan konsep pendidikan Islam karena di dalamnya memuat tujuan pendidikan Islam yaitu pendidikan rohani, pendidikan jasmani, dan pendidikan sosial.
\end{abstract}

Kata Kunci : Pembinaan, Perilaku, Remaja , IPTEKs

\section{PENDAHULUAN}

Perkembangan zaman yang semakin modern, dipengaruhi oleh perkembangan IPTEK yang pesat menimbulkan dampak positif dan negatif. Di sisi lain perkembangan IPTEK memberikan kemudahan bagi dunia pendidikan, tetapi di sisi yang lainnya penggunan yang tidak tepat memberikan dampak negatif bagi remaja itu sendiri, mulai dari lupa waktu menggunakan teknologi, kurang bersosialisasi karena fokus dengan gawainya belum lagi pengaruh-pengaruh lain yang sedikit banyak membentuk perilaku remaja. Seperti dilansir dalam sebuah harian online Republika.co.id (2016) bahwasanya 97\% remaja Indonesia pernah mengakses pornografi. Hal tersebut menunjukkan bahwa remaja tidak siap untuk dapat menyaring perkembangan IPTEK itu sendiri. Kemajuan 
IPTEK yang tidak dibarengi dengan peningkatan iman dan taqwa menjadi faktor utama yang menyebabkan remaja terdampak buruk dan memiliki perilaku menyimpang.

Di tengah perkembangan zaman ini, keluarga tidak bisa secara mutlak menjadi pembina perilaku remaja, karena berbagai faktor kesibukan, oleh sebab itu orangtua meminta bantuan kepada sekolah-sekolah untuk turut andil dalam membina perilaku remaja. Pembinaan di sekolah yang diberikan khusunya untuk sekolah umum yang bukan berbasis Islam adalah pembinaan sesuai standar pendidikan yang berlaku, yakni dengan adanya pelajaran pendidikan agama Islam yang pada kurikulum terbaru diwajibkan 4 jam dalam seminggu, beberapa sekolah memberikan program tambahan dalam pembinaan perilaku remaja seoptimal mungkin. Akan tetapi orangtua dan sekolah tidak bisa menjangkau pembinaan perilaku keberagamaan remaja secara sempurna, karena ruang hidup remaja bukan hanya di keluarga, dan sekolah saja. Mereka memiliki ruang lain yakni lingkungan masyarakat untuk bergaul, sehingga peran lingkungan masyarakat juga sangat dibutuhkan untuk membina perilaku keberagamaan remaja.

Salah satu faktor dominan yang mempengaruhi proses perkembangan individu menurut Makmun (2007) adalah faktor lingkungan (enviroment) yang merupakan kondisi yang memungkinkan berlangsungnya proses perkembangan (Abin Syamsudin, 2007, h.81). Hal tersebut menunjukkan bahwa jika kita menginginkan remaja memiliki perilaku keberagamaan yang baik, tentunya memerlukan dukungan yang kondusif dari lingkungan itu sendiri. Ketika di lingkungan keluarga remaja memiliki orangtua untuk senantiasa mengawasi, ketika di sekolah ada guru yang membantu mengawasi, dan ketika di lingkungan masyarakat kita membutuhkan masyarakat yang senantiasa mengawasi. Belum lagi dewasa ini guru banyak dituntut untuk dapat menginternalisasi nilai-nilai spiritual kepada remaja, begitu banyak tanggung jawab yang diberikan kepada guru . Melihat kondisi tersebut sangat tidak mungkin jika hanya guru yang harus berperan aktif dalam pembinaan remaja, ditengah-tengah pelajaran PAI yang berdurasi 4 jam dalam seminggu, sangat sulit untuk membentuk perilaku keberagamaan remaja menjadi yang diharapkan, oleh sebab itu guru sangat membutuhkan bantuan orangtua untuk mengkondisikan remaja ke lingkungan masyarakat yang kondusif. Tidak semua masyarakat dapat mengawasi remaja, sehingga orangtua seharusya mengarahkan remaja kelingkungan masyarakat positif yang dapat membentuk perilaku keberagamaan remaja, dan tempat yang dianjurkan adalah masjid.

Masjid sebagai tempat peribadatan umat muslim merupakan lembaga pendidikan non formal yang dapat turut andil membina perilaku keberagamaan remaja. Peranan masjid di era modern ini mulai terkikiskan, perserta didik cenderung meninggalkan masjid karena konsep pembinaannya masih tradisional, program-program yang ditawarkanya tidak menarik bagi remaja cendurung monoton, orangtua juga tidak dapat berupaya mengarahkan remaja dekat dengan masjid. Terutama pada remaja jenjang SMP dan SMA mereka mulai gengsi untuk mengikuti pembinaan di masjid. Bisa kita lihat remaja yang rutin mengikuti pengajian TPA/TPQ biasanya mereka tidak melanjutkan lagi ketika sudah memasuka jenjang SMP. Seperti menurut Ramayulis (2016 : 63) ide dasar keyakinan agama yang diterima remaja pada masa anak-anak, 
sudah tidak begitu menarik lagi bagi mereka. Mereka sudah mulai memiliki sifat kritis terhadap ajaran agama, merekapun juga mulai tertarik pada masalah kebudayaan, sosial, ekonomi, dan norma-norma kehidupan lainna di samping masalah agama. Terutama di era modern dan digital ini remaja lebih memilih untuk melakukan aktivitas lain yang sifatnya kekinian, yang sesuai dengan perkembangan zaman.

Masjid Salman ITB memiliki program-program pembinaan perilaku remaja yang sesuai dengan perkembangan zaman modern. Program yang ditawarkan yakni program pembinaanya yang telah berbasis IPTEKs (ilmu pengetahuan teknologi dan seni). Pembinaan perilaku keberagamaan di masjid Salman ini juga sudah terklasifikasi di mana ada pengelompokan tersendiri untuk jenjang TK, SD, SMP hingga SMA. Untuk jenjang SMP/SMA yang akan menjadi kajian penelitian ini dinaungi oleh Keluarga Remaja Masjid Salman ITB ( KARISMA ITB). Akan tetapi program pembinaan remaja di Masjid Salman belum bisa menjaring banyak remaja di kota bandung, rata-rata jumlah remaja yang sudah terjaring pembinaan untuk jenjang SMP dan SMA pada tahun 20172015 berkisar 1.500 remaja, padahal jumlah murid SMP dan SMA kota bandung menurut data statistik dinas pendidikan di kota Bandung untuk update pada tahun ajaran 2017/2018 adalah 175.378 remaja, hal tersebut menunjukkan bahwa pembinaan remaja di Masjid Salman ITB baru bisa menjaring sekitar 0,86 \% remaja kota Bandung. Hal tersebut menunjukkan sedikit sekali remaja yang mengikuti program pembinaan keberagamaan di Masjid Salman ITB. Berdasarkan fenomena tersebut, perlu dilakukan penelitian lebih lanjut supaya ditemukan data yang valid dan akurat serta sekaligus dapat ditentukan alternatif pemecahannya.

Pembinaan perilaku keberagamaan berbasis IPTEKs diharapkan menjadi suatu inovasi dan kreatifitas lembaga masyarakat dalam mendukung pembinaan perilaku keberagamaan remaja yang islami. Menurut Arifin dalam Abuddin Nata (2003) strategi pendidikan Islam dalam mengantisipasi kemajuan IPTEK modern, adalah bergantung pada kemampuan mengkonfigurasi sistem nilai Islam yang mengakomodasi terhadap aspirasi umat Islam untuk berpacu dalam kompetensi bidang IPTEK di satu pihak, dan kemampuan psikologis dan pedagogis yang berdaya kreatif untuk mentranfer IPTEK modern itu sendiri di lain pihak (Abudin Nata, 2008, h. 170). Sehingga untuk mengantipasi kemajuan IPTEK agar eksitensi Islam ditengah arus globalisasi tetap mempuni, perlu ada pembinan keberagmaan yang menjadikan IPTEK dan seni sebagai basisnya, sehingga kelak kemajuan IPTEK dan seni akan bermuara pada nilai-nilai Islam dan berdampak pada perilaku remaja sendiri, dan kekhawatiran akan pengaruh buruk IPTEK dalam jangka panjang terantisipasi dengan baik. Sehingga tujuan pendidikan Islam yang ingin menjadikan manusia sempurna atau insan kamil, seimbang antara IMTAQ dan IPTEK akan tercapai.

\section{METODE PENELITIAN}

Pendekatan yang peneliti gunakan dalam penyusunan penelitian ini adalah pendekatan secara kualitatifif. Pendekatan secara kualitatif dimaksudkan untuk memperoleh jawaban penelitian secara deskriptif analitik mengenai konsep, implementasi, keefektifan dan faktor pendukung serta penghambat pembinaan perilaku 
keberagamaan remaja berbasis IPTEKs. Sehingga dapat menjawab seluruh rumusan masalah yang ada. Sumber data dalam penelitian ini adalah data primer yaitu wawancara dengan remaja binaan di Lembaga Pendidikan KARISMA ITB . Sumber data dalam penelitian ini adalah data primer yaitu wawancara dengan remaja binaan di Lembaga Pendidikan KARISMA ITB. Subyek penelitian ini adalah remaja binaan yang memenuhi berbagai kriteria antara lain; remaja, usia 13 hingga 17 tahun, pendidikan jenjang SMP dan SMA, pernah mengikuti pembinaan di KARISMA ITB minimal 4 kali pertemuan, dan berdomisili di bandung. Dari subyek penelitian tersebut diketahui secara jelas keefektifan pembinaan perilaku keberagamaan peserta remaja berbasis IPTEKs. Sedangkan data sekunder bersumber dari wawancara dengan enam orang pembina di Lembaga Pendidikan KARISMA ITB, serta dokumen-dokumen yang terkait konsep pembinaan perilaku keberagamaan remaja di lembaga pendidikan KARISMA ITB, sehingga dapat diketahui dengan jelas konsep, implementasi dan faktor pendukung dan penghambat pembinaan perilaku keberagamaan berbasis IPTEKs.

\section{HASIL TEMUAN DAN PEMBAHASAN}

Berdasarkan hasil penelitian pembinaan perilaku keberagamaan remaja berbasis IPTEKs di Lembaga Pendidikan KARISMA ITB, pembinaan tersebut memiliki konsep pembinaa dimulai dari tujuan, metode pembinaan, materi pembinaan, dan kelompok minat remaja. Tujuan pertama dari pembinaan anggota remaja di KARISMA adalah menumbuhkan ketertarikan untuk mempelajari Islam dengan proses pembinaannya yaitu: mengikat hati membangun kedekatan antar sesama anggota dan meenginternalisasi nilai KARISMA . Tujuan kedua setelah remaja tertarik mempelajari Islam yaitu membangun kepribadian Islami. Proses pembinaannya adalah sebagai berikut: membentuk aqidah,membentuk aktivitas ibadah membentuk akhlaq Islami, membentuk jiwa sosial-masyarakat, membentuk perasaan, membentuk jasmani, menanamkan cinta ilmu, memelihara kesehatan dan mengarahkan kecenderungan seksual. Tujuan ketiga setelah kepribadian Islami terbentuk adalah membangun kepribadian pendakwah dengan proses pembinaaannya adalah: membentengi dari pola pikir dan perilaku menyimpang, memberikan pengetahuan tentang kondisi umat saat ini, menanamkan spirit dakwah.Tujuan keempat atau terakhir dari pembinaan anggota remaja di KARISMA adalah membangun pendakwah yang berdakwah secara berjamaah dengan proses pembinaannya menanamkan pentingnya amal jama'i.

Berkaitan dengan kesesuaian materi dan aspek pembinaann KARISMA ITB, dengan inti tujuan pendidikan Islam menurut teori Educaitonal Theori, a quranic outlock yang digagas oleh Abdurrahman Sholeh dalam Ahmad Suryadi (2017) menyebutkan ada empat inti pendidikan Islam yaitu: Tujuan pendidikan Jasmani, tujuan pendidikan ruhani, tujuan pendidikan akal, dan tujuan pendidikan sosial (Rudi Ahmad, 2017, h. 153). Dari hasil diperoleh bahwa tujuan pembinaan perilaku keberagamaan berbasis IPTEKs di KARISMA ITB telah sesuai dengan tujuan pendidikan Islam, karena terdapat tujuan pendidikan jasmani berupa pembinaan di KARISMA ITB membentuk jasmani yang sehat, lalu tujuan pendidikan rohani berupa membentuk aqidah remaja yang kokoh, selanjutnya yaitu tujuan pendidikan akal yakni karisma berupaya 
menanamkan para remaja untuk cinta ilmu melalui pengaplikasian IPTEKs, dan tujuan pendidikan Islam yang terakhir yang terdapat pada pembinaan di KARIMA ITB adalah tujuan pendidikan sosial berupa membentuk jiwa remaja agar dapar bersosial dan bermasyarakat sesuai norma yang berlaku.

Metode pembinaan yang dapat digunakan dalam pembinaan keberagamaan menurut al-Nahlawi dalam Ahmad Tafsir (2010) antara lain, metode hiwar, metode kisah, metode amtsal, metode keteladanan, metode pembiasaan, metode ibrah dan mauizah, dan metode targhib dan tarhib (Ahmad Tafsir, 2012, h. 201). Pembinaan perilaku keberagamaan di ITB menggunakan metode yang banyak dicontohkan untuk membina perilaku dalam islam metode utama pembinaan di KARISMA ITB adalah metode mentoring. Dalam metode mentoring di KARISMA ITB terdapat pembiasaan ibadah. remaja selalu dipastikan telah melaksanaan sholat wajib sebelum kegiatan dimulai, lalu mereka mulai diajak melaksanakan sholat dhuha dan membaca al-quran dengan rutin. Aspek keteladanan juga diberikan dalam metode mentoring dengan bentuk berupa kisah rosul, menonton film pendek, dan mempraktekan langsung seperti mengunjungi panti asuhan. pembinaan perilaku keberagamaan remaja berbasis IPTEKs memudahkan remaja menganoligikan perumapaman-perumpamaan dalam al-quran dengan pecobaan sains, atau dengan kata lain pembinaan perilaku keberagmaan remaja berbasis IPTEKs memudahkan remaja menganalogikan bentuk abstrak ke dalam bentuk konkrit sehingga mudah memahami ajaran islam.

Lembaga Pendidikan KARISMA ITB memberikan pilihan-pilihan tertentu dalam bidang IPTEKs, ada kelompok remaja seni, kelompok remaja sains, kelompok remaja, media teknologi dan kelompok remaja bimbingn belajar, sehingga remaja dapat memilih kelompok pembinaan sesuai dengan baik dan minat mereka. Hal tersebut menjadi daya tarik dan keunggulan sendiri bagi lembaga pendidikan KARISMA ITB. Sesuai dengan yang dijelaskan Albert Bandura dalam Syamsu Yusuf (2014) menjelaskan bahwa mekanisme sosial harus memfasilitasi harapan-harapan remaja, perubahan tingkah laku remaja banyak diperoleh dari hasil pengalaman-pengalaman yang langsung yang mereka rasakan, dan sumber pokok yang berbengaruh terhadap perubahan perilaku remaja sendiri (Syamsul Yusuf, 2012, h. 190).

Pembinaan dengan sains memiliki beberapa kegiatan antara lain Science Around You, Science Experiment, Quiz Day, dan Science Project. Kegiatan Science Around You dilaksanakan 2 hari yang bertujuan untuk menumbuhkan kepekaan terhadap fenomena sains di lingkungan sekitar dan keberanian menyampaikannya dan menumbuhkan keinginan remaja dalam memahami fenomena sains dan keterkaitannya dengan dunia islam. Science Around You merupakan suatu kegiatan dimana remaja diajak untuk melihat fenomena sains di alam terbuka, kemudian mereka diajak mengkaji fenomena tersebut dari sudut pandang sains dan islam, serta menghubungkan keduanya dengan realita sebenarnya. Lalu remaja akan ditantang untuk menjadi "pencerita sains" dengan caranya sendiri. Kegiatan inti terdiri dari memerah dan memandikan sapi, planetarium, mentoring keagamaan oleh tim sains. 
Kegiatan sains yang ke dua adalah Science Experiment yang bertujuan agar remaja mampu melakukan dan memahami eksperimen sains, remaja mampu berpikir secara ilmiah, dan meningkatnya minat remaja untuk mendalami ilmu sains. Science Experiments merupakan percobaan, simulasi, dan demonstrasi sains sederhana dengan memanfaatkan benda/fenomena alam di sekitar yang meliputi bidang keilmuan fisika, kimia, dan biologi. Kemudian dijelaskan hikmah dan kaitannya dengan semesta alam (dengan ayat Al-Qur'an yang dikutip). Kegiatan Science Experiment ini berlangsung selama empat kali pertemuan.

Kegiatan sains yang ke tiga adalah quiz day, tujuan kegiatan ini Meningkatkan pemahaman remaja tentang perkembangan dan fenomena sains serta sains dalam dunia Islam. Banyak sekali remaja islam yang pemahamannya terkait islam dan peradabannya masih minim. Selain daripada itu, merekapun masih kesulitan dalam memahami dan menjelaskan kembali fenomena-fenomena sains yang sebetulnya terjadi disekitar kita setiap saat. Di sisi lain, remaja cenderung antusias melakukan hal-hal yang mereka lihat di televisi seperti reality show dan quiz show. Dimana pengetahuan dan pembelajaran dikemas dalam bentuk yang menarik. Kegiatan ini berupa memberikan informasi tentang sains dan dunia islam dengan bentuk quiz. Kegiatan ini berlangsung selama satu kali pertemuan.

Kegiatan sains yang ke empat adalah Science Project yang bertujuan agar remaja dapat mengekspresikan diri dengan menghasilkan karya dan remaja dapat mengaplikasikan ilmu yang telah dipelajari. Science Project secara sederhana adalah project berkelompok yang dilakukan oleh adik sains. Adik tim sains dibentuk menjadi 3 kelompok sesuai bidang keilmuan. Masing-masing bidang ilmu membuat produk sains sebagai bentuk berekspresi sesuai minat adik di bawah pengawasan pembina. Kegiatan ini dilaksanakan satu kali pertemuan.

Pada seni terdapat beberapa kegiatan antara lain, ekplore seni, design grafis, dan kreasi barang seni. Bentuk kegiatan ekplore seni yaitu remaja dan pembina akan melakukan kunjungan atau jalan-jalan ke kampong kreatif di Dago Pojok. Kegiatan akan dikemas dengan konsep game atau permainan yang bisa menambah keakraban antara adik dan pembina, misal dengan membagi dalam beberapa tim, lalu tiap tim diberikan misi berupa kumpulan foto yang harus dicari barang aslinya di kampung kreatif tersebut. Apabila sudah ditemukan barang yang ditentukan, remaja diminta untuk menjelaskan atau menebak jenis dari hasil karya tersebut.

Desain grafis adalah bentuk kegiatan tim seni dimana remaja diperkenalkan dengan aplikasi desain grafis lalu diberikan pengetahuan mengenai dasar-dasar sekaligus beberapa teknik desain grafis. Remaja diminta untuk membuat desain karya mereka sendiri dan dipresentasikan kepada remaja yang lain. Program ini menjadikan remaja mendapatkan pengetahuan mengenai software photoshop, remaja bisa menggunakan teknik dan tools dengan baik, remaja menerapkan kreatifitasnya dalam membuat desain grafis dan puncaknya remaja membuat desain grafis untuk dakwah. Kegiatan ini dilaksanakan 3 kali pertemuan. 
Kreasi barang seni merupakan kegiatan tim seni yang bertujuan Menyalurkan kreatifitas dan keterampilan remaja melalui karya seni, remaja menghasilkan sebuah karya, dan remaja bekerja dalam kelompok. Kegiatan ini dilaksanakan sebanyak 3 kali peretemuan tempatnya outdor di sekitar Masjid Salman ITB. Bentuk kegiatan ini berupa, remaja diberikan pembinaan mengenai pembuatan barang-barang yang bernilai seni (dengan menggunakan bahan clay, membuat kreasi lampu tidur, dan menghias wadah untuk alat tulis) dan langsung mempraktekkannya bersama-sama. Di akhir kegiatan remaja diminta untuk menceritakan maksud dari hasil karya seni yang dibuatnya sekaligus pengalaman yang dirasakan saat bekerja sama dengan kelompoknya.

Program media teknologi terdapat dua kegiatan yang pertama yaitu Ta'aruf Fotografi dan Videografi. Tujuan kegiatan ta'aruf fotografi dan videografi adalah remaja mampu melakukan proses pengambilan gambar untuk foto dan memproses setelahnya, remaja bisa menyampaikan pesan dalam bentuk visual, lisan dan tulisan. Ini merupakan program pembinaan rutin untuk 4-5 minggu pembinaan tim media. Deskripsi masing-masing minggunya :

1. Teknik Fotografi, pada minggu ini, remaja belajar komposisi dan angle kamera untuk mengambil gambar Foto.

2. Foto Editing, pada minggu ini, remaja belajar bagaimana cara mengedit foto. Pada pembinaan ini, pengeditan menggunakan software editor foto yang akan diberikan dan adik diharapkan membawa laptopnya masing-masing.

3. Teknik videografi, pada minggu ini, remaja a belajar komposisi, angle kamera, dan pergerakan kamera. Selain itu akan diajarkan teknik pengambilan video untuk dialog, dan 'cinematic videography'.

4. Video Editing, pada minggu ke-lima, remaja belajar bagaimana cara mengedit video. Pada pembinaan ini, pengeditan menggunakan software editor video yang akan diberikan dan adik diharapkan membawa laptopnya masing-masing.

Kegiatan tim media teknologi yang kedua adalah Media Challenge, tujuan kegiatan ini adalah remaja mampu membuat video pendek karya sendiri sebagai media dakwah, tausiyah, pesan-pesan moral dan motivasi positif. Kegiatan ini diselesaikan dalam 2 pertemuan berupa :

1. Pada minggu pertama remaja diperkenalkan teknik-teknik pembuatan konten yang bagus untuk membuat konsep awal video pendek yang akan dibuat, kemudian remaja menyelesaikan naskah lengkap maksimal 3 hari setelahnya

2. Pada hari ahad berikutnya, remaja melaksanakan proses shooting dan editing untuk naskah yang telah dikonsep, pengumpulan hasil karya dilakukan di akun sosial media remaja dan akun sosial media Karisma maksimal 1 minggu setelah proses shooting.

Keberjalanan pembinaan perilaku keberagamaan berbasis IPTEKs di KARISMA ITB sesuai dengan konsep pembinaan yang telah dirumuskan. Materi pembinaan IPTEKs di KARISMA ITB telah sesuai dengan teori Menurut Linda Richard Eyre dalam A. Tafsir dkk (2004) bahwa dalam membina perilaku harus ada nilai-nilai nurani dan 
nilai-nilai memberi (Tafsir,h.312). Pembinaan di KARISMA ITB memasukan nilainilai nurani seperti mencintai lingkungan, dan adab kepada orang tua, dan nilai-nilai memberi seperti etika bergaul dan adab berkomunikasi.

Keefektifan pembinaan perilaku keberagamaan remaja berbasis IPTEKs di KARISMA ITB diukur berdasarkan aspek keberagamaan yang dirumuskan oleh C.Y Glock dan R.Stark (1965) mengenai dimensi keberagamaan yaitu dimensi keyakinan (Ideological Dimension) , dimensi peribadatan atau peraktek agama (Ritualistic Dimension), dimensi penghayatan (Eksperiental Dimension), dimensi pengalaman (Consequential Dimension), dimensi pengetahuan agama (Intellectual Dimensin). Pada aspek keyakinan atau aqidah setelah pembinaan perilaku keberagama berbasis IPTEKs remaja merasa percobaan sains membuat mereka bisa langsung praktek dan melihat keilmuan dari sudut pandang islami, membuat mereka bersikap semakin yakin dengan ajaran islam. Sikap sendiri menurut Muhibbin syah (2004), merupakan pandangan atau kecenderungan mental seseorang ${ }^{6}$. jika melihat dari hasil wawancara kepada remaja, kecenderungan-kecenderungan remaja setelah mendapatkan pembinaan keberagamaan berbasis IPTEKs, terlihat mereka memiliki kecenderungan baru yang lebih dan positif.

Pada aspek peribadatan atau praktek agama, remaja dibiasakan untuk mendahulukan sholat dibandingkan mengerjakan pekerjaan rajin. Metode pembiasaan efektif untuk membina perilaku yang berkaitan dengan moral atau kegamaan. Seperti menurut Muhibbin Syah (2004:120) tujuan pembiasaan adalah memperoleh sikapsikap dan kebiasaan baru yang lebih tepat dan positif, makna positif sendiri adalah selaras dengan norma dan baik yang bersifat religius. Pembiasaan sholat terbukti efektif dalam membinan perilaku keberagaman bisa dilihat dari jawaban wawancara remaja yang menyebutkan bahwa mereka rajin dan disiplin dalam meklaksnakan sholat. Mereka bahkan telah mengerti bahwa bukan hanya akademik yang harus dikejar tapi sholat merupakan prioritas wajib. Remaja juga mulai paham bahwa bukan hanya urusan dunia saja yang haru dikejar tapi akhirat juga. Peningkatan ibadah juga terlihat dari remaja yang mulai melaksanakan ibadah sunah seperti puasa, sholat rawatib, dan tahajud.

Pada aspek penghayatan yang dapat dicerminkan dengan akhlak, diketahui bahwa pembinaan perilaku khususnya perilaku sosial dilakukan dalam kegiatan mentoring, biasanya remaja diberikan cerita Rosul atau sahabat-sahabatnya sebagai contoh. Cerita membuat mereka lebih berkesan dan paham langsung tetang bagaimana berahklak baik dan langsung mengena di hati mereka. Hikmah dalam cerita membuat remaja dapat meneladani perbuatan-perbuatan baik yang diajarkan Rosulullah, dan tahu langsung keutamaan pebutan tersebut. Hikmah sendiri menurut Zaqiah (2010) merupakan keadaan jiwa dimana seseorang dengnnya bisa membedakan baik dan buruk (Qiqi Yuliati Zakqiah, 2010, h. 12). Sehingga metode cerita sangat baik bagi remaja dalam menemukan hikmah. Dari hasil wawancara remaja , mereka menyebutkan bahwa setelah melaksanaan pembinaan keberagamaan berbasis IPTEKs mereka menjadi pribadi yang lebih baik. Remaja menyebutkan mereka merasa lebih ramah, bisa 
menghargai orang lain, dan yang paling menonjol mereka merasa lebih berani dan percaya diri jika mengemukakan pendapat. Hal tersebut sesuai dengan kebijakan sosial yang direkomendasikan oleh carneige council on adelescent development (1995) bahwa penggunaan IPTEK harus mendorong program yang bertujuan meningkatkan tanggung jawab sosial.

Pada aspek pengetahuan agama, pembinaan keberagamaan berbasis IPTEKs menekankan pada praktek langsung, remaja dibina keagamaanya lalu diajarkan bagaimana membuat produk keagamaan langsung, mereka diajak langsung berdakwah seperti membuat video pendek yang berisi tausiyah atau motivasi, mereka juga diajak mengkaji sains dalam Al-quran. Hal tersebut sesuai dengan metode yang digagas Syamsul Arifin (2008) bahwa metode pembinaan remaja harus dapat mendekatkan agama dengan kehidupan. Dengan program-program yang melibatkan praktek langsung terbukti mereka lebih tertarik dan merasakan mudah memahami karena langsung diaplikasikan.

Aspek terakhir adalah pengalaman religius atau pengalaman beragama yang didapatkan remaja sejatinya berdampak pada perilaku keberagamaan mereka. Jika kita lihat dalam aliran behaviorisme bahwa perilaku dapat dimunculkan dengan stimulusstimulus tertentu atau lebih jelasnya terdapat pada teori operant conditioning yang menyebutkan bahwa perilaku terpancarkan berdasarkan stimulus tertentu. Seperti menurut Santrock (2007), Operant Conditioning adalah sebentuk pembelajaran di mana konsekuensi-konsekunsi dari perilaku menghasilkan perubahan dalam probabilitas perilaku itu akan diulangi. Remaja berdasarkan hasil wawancara mengatakan bahwa ketika kehidupanyya tidak mengejar dunia, dan lebih banyak mengharapkan ridho-ridho Allah ia merasa bahwa justru Allah memudahkannya dalam urusan dunia. Hal tersebut dapat diibaratkan reinforcement atau penguat positif, dimana ketika ia melakukan perbuatan baik, Allah memudahkannya dalam uruan dunia. Selain itu remaja juga merasakan hidupnya lebih tenang ketika belajar agama islam, dan membuat mereka terus ingin bahkan mencari forum-forum kajian keislaman di luar KARISMA ITB. Dari pengukuran ke lima aspek keberagamaan dapat diketahui bahwa pembinaan perilaku kebaragamaan berbasis IPTEKs di KARISMA ITB telah efektif membinan perilaku keberagamaan remaja.

Faktor menonjol yang sangat dominan sebagai pendukung pembinaan di KARISMA ITB adalah IPTEKsnya sendiri, IPTEKs sendiri merupakan media yang sangat diminati remaja saat ini, IPTEKs sesuai dengan perkembangan zaman, sehingga remaja sangan tertarik mengkajinya. Ketertarikan remaja akan keterampilanketarampilan dan tugas secara langsung dijelaskan Albert Bandura dalam Syamsu Yusuf (2014) menjelaskan bahwa mekanisme sosial harus memfasilitasi harapanharapan remaja, perubahan tingkah laku remaja banyak diperoleh dari hasil pengalamanpengalaman yang langsung yang mereka rasakan, dan sumber pokok yang berbengaruh terhadap perubahan perilaku remaja sendiri mencangkup: 
1) Pengembangan keterampilan yang kondusif, remaja diberikan pengalaman dan kesempatan untuk mengobrservasi perilaku orang lain, sehingga ia bisa menampilkan perilaku yang layak.

2) Pengalaman yang beragam, remaja harus diberikan kesempatan untuk memandang model-model simbolis sehingga memberikan sumber informasi penting yang dapat meningkatkan harapan-harapan remaja.

3) Persuasi verbal seperti sugesti dan teguran

4) Penciptaan situasi yang mengurangi dorongan emosional, tetapi lebih kepada meningkatkan kompetensi (Syamsul Yusuf, 2012, h. 190).

Dari hal tersebut KARISMA ITB telah berhasil menciptakan situasi dimana remaja-remaja merasakan harapan-harapan mereka terpenuhi, dengan pembinaan keberagamaan berbasis IPTEKs yang sesuai dengan minat bakat mereka. Pembinaan dengan IPTEKs mengkondisikan mereka untuk mencoba dan mengaplikasikan langsung suatu kegiatan bahkan menyangkut hak keislaman, itu membuat mereka merasakan pengalaman-pengalaman kegamaan dan membuat perilaku remaja menjadi lebih baik. Pembinaan keberagamaan berbasis IPTEKs mendukung remaja lebih menyalurkan energinya kepada bakat dan minat, mampu meredam kegoncangan dirinya serta hasrat seksual, yang biasa dialami pada usia remaja.

Sedangkan faktor penghambat seperti kekurangan SDM pembina wajar terjadi karena cakupan seni, sains, teknologi sangatlah luas, KARISMA ITB perlu mengkaji kekurangan-kekurangan sumber daya secara spesisifik, sehingga terlihat jelas apa saja yang menjadi kebutuhan untuk pembinaan remaja periode selanjutnya. Penelitian tentang potensi bakat minat remaja di bidang IPTEKs di kota bandung perlu dilakukan sehingga , KARISMA ITB dapat mengetahui dengan pasti apa yang menjadi harapanharapan remaja kota bandung dan mengambil kesempatan untuk mengembangkan potensi tersebut sebagai daya tarik pembinaan perilaku kebaragamaan berbasis IPTEKs yang lebih baik dan luas cangkupannya.

\section{SIMPULAN}

Berdasarkan pembahasan di atas dapat, disimpulkan sebagai berikut :

1. Konsep pembinaan perilaku keberagamaan berbasis IPTEKs di Lembaga Pendidikan KARISMA ITB telah sesuai dengan Konsep pendidikan Islam. Karena terdapat metode-metode islami yang digunakan dalam pembinaanya dan tujuan pembinaan perilaku keberagamaan berbasis IPTEKs di KARISMA ITB juga telah sesuai dengan tujuan pendidikan Islam.

2. Implementasi pembinaan perilaku keberagamaan remaja berbasis IPTEKs telah sesuai dengan konsep yang dirumuskan. Pelaksanaan program telah berjalan sesuai jadwal. Akan tetapi penggunaan IPTEKs belum dapat meliputi semua materi pembinaan keislaman yang terdapat dalam konsep pembinaa remaja KARISMA ITB.

3. Pembinaan berbasis IPTEKs di KARISMA ITB telah efektif membina perilaku keberagamaan remaja menjadi lebih baik, dapat dilihat dari hasil pengukuran 
berdasarkan 5 aspek keberagamaan berupa keyakinan atau aqidah, peraktek keagamaan, penghayatan yang berupa akhlak, pengetahuan agama dan pengalaman religious bahwa terdapat perubahan perilaku remaja kearah yang lebih baik.

4. Faktor pendukung dan penghambat pembinaan perilaku keberagamaan remaja berbasis IPTEKs di lembaga pendidikan KARISMA ITB berupa; faktor pendukung yang teridentifikasi adalah penggunaan IPTEKs memudahkan dalam pembinaan perilaku keberagamaan, remaja tersalurkan minat bakatnya di bidang IPTEKs, remaja dapat memanfaatkan gadget yang dimilikinya, orang tua mendukung program-program yang diberikan, mentoring keagamaan yang terbungkus IPTEKs membuat remaja tidak menyadari secara langsung mereka sedang dibina keberagamaanya, para pembina yang memiliki latar belakang pendidikan berbeda-beda, IPTEKs memungkinkan menganalogi hal-hal yang bersifat asbstrak menjadi konkrit, IPTEKs menjadikan nilai jual sehingga para remaja mau tergabung dalam pembinaan keberagamaan yang dilaksanakan KARISMA ITB.

Sedangkan faktor penghambat yang teridentifikasi adalah ; belum semua pembina menguasai bidang IPTEKs yang menjadi program, IPTEKs sendiri cangkupannya luas sehingga belum terwadahi semua, remaja SMP dan SMA memiliki wawasan yang berbeda sehingga sulit melakukan pembinaan IPTEKs secara bersama, bidang IPTEKs belum sepenuhnya memenuhi minat remaja, dan penggunaan IPTEKs memerlukan dana.

\section{DAFTAR PUSTAKA}

Abuddinnata . 2003. Kapita Selekta Pendidikan Islam. Bandung: Angkasa

Ahmad Suryadi, Rudi. 2017. Rekontruksi Pendidikan Islam. Bandung: Penerbit Nuanasa.

Konsep Pembinaan Remaja KARSIMA ITB 1436 H. Dokumen organisasi : Tidak diterbitkan

Ramayulis, 2016. Psikologi Agama.. Jakarta : Kalam Mulia

Republika. 2016. 97 Persen Remaja Indonesia Pernah Mengakses Pornografi. Tersedia [Online]

http://nasional.republika.co.id/berita/nasional/hukum/16/10/11/oew0yb361-97persen-remaja-indonesia-pernah-mengakses-pornografi. Diakses 2 februari 2018

Santrock, John. 2017. Life Span Development Perkembangan Masa Hidup Jilid II.. Jakarta: Erlangga

Syah, Muhibbin, 2004. Psikologi Pendidikan.Bandung : PT Remaja Rosdakarya

Syamsuddin Makmun, Abin. 2007. Psikologi Kependidikan . Bandung:Rosda

Syamsul Arifin, Bambang. 2008. Psikologi Agama . Bandung: Pustaka Setia

Tafsir dkk. 2004. Cakrawala Pemikiran Pendidikan IslamBandung: Mimbar Pustaka ${ }^{1}$ C.Y Glock, C.Y \& R.stark. 1965. Religion and Society in Tension . U.S.A : Rand Mc Nally \& Company

Tafsir, Ahmad. 2012. Ilmu Pendidkan Islami. Bandung: Rosda. 
Pembinaan Perilaku Keberagamaan..

Yusuf , Syamsu. 2012. Psikologi Perkembangan Anak dan Remaja. Bandung: Remaja Rosdakrya.

Zaqiah, Qiqi Yuliati.2010. Kuliah-kuliah Akhlaq Karya Imam Ghazali. Bandung: Sega Arsy 